\title{
On the Effects of Acid Pre-treatment on the Elemental and Isotopic Composition of Lightly- and Heavily-calcified Marine Invertebrates
}

\author{
Georgios Kazanidis $^{1,2 *}$, Solveig Bourgeois ${ }^{1}$, and Ursula F. M. Witte ${ }^{1}$ \\ ${ }^{1}$ Oceanlab, School of Biological Sciences, University of Aberdeen, Newburgh AB41 6AA, UK \\ ${ }^{2}$ Grant Institute, School of Geosciences/ATLAS project, University of Edinburgh, Edinburgh EH9 3FE, UK
}

Received 6 August 2018; Revised 21 October 2018; Accepted 28 December 2018

(C) The Author(s) 2019

\begin{abstract}
Carbonate removal using acids is a common practice in ecological studies. The effects, however, of acid pre-treatment on the elemental and isotopic composition of marine invertebrates as well as how these effects vary according to species' carbonate content is little known. We examined the effects of acid pre-treatment on the elemental $(\% \mathrm{C}, \% \mathrm{~N}, \mathrm{C}: \mathrm{N}$ ratio $(\% \mathrm{C}: \% \mathrm{~N}))$ and isotopic composition $\left(\delta^{13} \mathrm{C}, \delta^{15} \mathrm{~N}\right)$ of 28 lightly- and heavily-calcified species from Cnidaria, Mollusca, Arthropoda, Bryozoa, Echinodermata and Chordata. The present study showed that acid pre-treatment modified the elemental and isotopic composition of lightly- and heavily-calcified marine invertebrates. The shifts were clearly seen as a decrease in the $\% \mathrm{C}$ and $\delta^{13} \mathrm{C}$ of heavily-calcified species while we did not detect a clear pattern for $\% \mathrm{~N}$ and $\delta^{15} \mathrm{~N}$ (in both lightly-and heavily calcified species). Apart from carbonates, acid pre-treatment caused also the loss of organic compounds, thus confounding the interpretation of carbonate proxy (CP) -a widely used proxy for carbonate content. We recommend the use of $\mathrm{CP}$ solely with heavily-calcified species. For the first time it was shown that the use of $\delta^{15} \mathrm{~N}$ values from acidified samples can introduce substantial bias in our perception about the number of trophic levels, the distribution of species and distribution of biomass across the trophic levels in a community. We have uncovered and elucidated previously unknown aspects and highlighted the challenge posed when predicting shifts in elemental and isotopic composition of species following acid pre-treatment. The present findings should be considered in future studies using acid pre-treatment as they can contribute to the optimum use of samples while avoiding bias in the interpretation of findings.
\end{abstract}

Keywords - acid pre-treatment, carbonate content, elemental composition, stable isotopes, food web

\footnotetext{
*Corresponding author. E-mail: georgios.kazanidis@ed.ac.uk
}

\section{Introduction}

The elemental and isotopic composition of organisms' organic compounds can provide ecologists with useful information about food-web structure and cycling of organic matter. Specifically, organic carbon and nitrogen content $(\% \mathrm{C}, \% \mathrm{~N})$ can be used in biomass estimations while stable isotope ratios $\left(\delta^{13} \mathrm{C}, \delta^{15} \mathrm{~N}\right)$ can reveal species' food sources and relative position in food webs (Frost et al. 2002, 2005; Sterner and Elser 2002; van Oevelen et al. 2009; Layman et al. 2012). In contrast to the organic carbon fractions, the inorganic forms of carbon (i.e. carbonates, $\mathrm{CaCO}_{3}$ ) do not reflect dietary sources. In addition, they exhibit enriched (i.e. higher) $\delta^{13} \mathrm{C}$ values and their presence can confound findings about species' diet and community trophic structure (e.g. Schlacher and Connolly 2014). In consequence, the removal of carbonates is very important when organic $\% \mathrm{C}$ and $\delta^{13} \mathrm{C}$ are investigated while it is not necessary in those studies focusing on organic $\% \mathrm{~N}$ and $\delta^{15} \mathrm{~N}$ since calcium carbonates do not contain nitrogen (Serrano et al. 2008). For some organisms, carbonate removal can be carried out mechanically (e.g. shells of large-sized bivalves). However, this approach is not always possible for small-sized invertebrates and some Phyla (e.g. echinoderms) (Mateo et al. 2008; Schlacher and Connolly 2014). In these cases, carbonate removal is carried out using acids which leads to the release of carbonates. The most-commonly used acids are hydrochloric $(\mathrm{HCl})$, sulphuric $\left(\mathrm{H}_{2} \mathrm{SO}_{3}\right)$ and phosphoric $\left(\mathrm{H}_{3} \mathrm{PO}_{4}\right)$ (King et al. 1998; Brodie et al. 2011; Schlacher and Connolly 2014). Carbonate removal using $\mathrm{HCl}$ has produced more coherent and reliable $\delta^{13} \mathrm{C}$ and $\mathrm{C} / \mathrm{N}$ data compared to the use of $\mathrm{H}_{2} \mathrm{SO}_{3}$ and $\mathrm{H}_{3} \mathrm{PO}_{4}$ (Brodie et al. 2011). Apart from 
the type of acid used, there is also variability in terms of the acid concentration used (e.g. $1-36 \%$ in the case of $\mathrm{HCl}$, Brodie et al. 2011 and references therein) and the means of application (e.g. direct application of the acid in the capsule containing the sample vs. acid fumigation, addition of a specific volume of acid vs. the addition of acid until the cessation of effervescence) (Bosley and Wainright 1999; Jacob et al. 2005; Søreide et al. 2006; Jaschinski et al. 2008; Serrano et al. 2008; Vafeiadou et al. 2013).

Apart from the removal of carbonates, acid pre-treatment can affect the organic fractions of carbon and nitrogen (Schlacher and Connolly 2014). This is important since measurements on the elemental and isotopic composition of carbon and nitrogen are often carried out in the same acidified sample to reduce preparation time and analytical cost. The effects of carbonate removal on the organic fractions of carbon and nitrogen are attributed to factors like loss of acid-soluble organic carbon during carbonate dissolution, volatilization of organic compounds, loss of material (e.g. fine particles) during pre-treatment, fractionation of organic matter during acid evaporation, preservation of organic matter with small $\delta^{13} \mathrm{C}$ value and limited analytical accuracy due to low $\mathrm{C}$ or $\mathrm{N}$ recovery in samples (Bunn et al. 1995; Serrano et al. 2008; Schlacher and Connolly 2014 and references therein).

To date, only a few groups of marine invertebrates (i.e. arthropods, molluscs, polychaetes -see Figure 2 in Schlacher and Connolly 2014) have been investigated regarding the effects of carbonate removal on their elemental and isotopic composition. Surprisingly, studies on groups common in marine ecosystems (e.g. echinoderms, bryozoans, ascidians) are absent and thus the extent of changes in their elemental and isotopic composition is unknown. Despite this absence of knowledge, previous works have used the $\delta^{15} \mathrm{~N}$ values from acidified samples of heavily-calcified organisms (e.g. Mintenbeck et al. 2007; Yokoyama et al. 2009; Iken et al. 2010; Feder et al. 2011; Sokolowski et al. 2014; Divine et al. 2015; Tu et al. 2015). Furthermore, it should be mentioned that previous works examining pre-treatment effects on species' composition were mainly focused on the direction and magnitude of shifts but did not investigate the possible effects on the interpretation of community trophic structure using acidified and non-acidified samples. This is important for $\delta^{15} \mathrm{~N}$ values since they are used for the calculation of species' trophic level (e.g. Post 2002). In addition, $\delta^{15} \mathrm{~N}$ values of primary consumers are used as a trophic baseline in food webs (Vander Zanden and Rasmussen 1999; Iken et al. 2010).
The present study is the first one to investigate the effects of acid pre-treatment on the elemental and isotopic composition of marine invertebrates from a large range of carbonate content [from lightly (e.g. arthropods) to heavily-calcified (e.g. echinoderms)] and the possible consequences of these effects on the interpretation of community trophic structure. It was hypothesized that carbonate removal would cause the depletion of $\% \mathrm{C}$ and $\delta^{13} \mathrm{C}$ values -especially in heavily-calcified organisms like echinoderms and calcified bryozoans- while such an effect was not expected for $\% \mathrm{~N}$ and $\delta^{15} \mathrm{~N}$. In addition, it was hypothesized that no differences in community trophic structure (number of trophic levels, distribution of species' number and biomass across the trophic levels) between the use of acidified and non-acidified $\delta^{15} \mathrm{~N}$ values would be found.

\section{Material and Methods}

\section{Study areas and collection of samples}

Macro- and megafauna were collected from cold-water coral reefs (CWCRs) in the northeast Atlantic and soft sediments in the east Canadian Arctic (see Table A1 in Appendix). During the cruise "JC073" on board the RRS "James Cook" in 2012, fauna living in association with the substratum-forming sponge Spongosorites coralliophaga (Stephens, 1915) that colonize coral rubble was collected from Mingulay reef complex and Logachev Mound in the northeast Atlantic using the remotely operated vehicle (ROV) "Holland I' (Roberts and Shipboard Party 2013).

The tight sampling schedule during the JC073 "Changing Oceans" expedition (where samples from two cold-water coral reefs were collected) did not allow for immediate taxonomic identification on board. In addition, freezing of specimens was not carried out in order to avoid damage to specimens that would impede the proper taxonomic identification of the specimens. As a response, the collected fauna was preserved in $10 \%$ seawater formalin and data were treated following previous studies (Gontikaki et al. 2011; Hunter et al. 2012; Jeffreys et al. 2013; Kazanidis and Witte 2016). Specifically, taking into account the findings from previous studies on the effects of formalin preservation on carbon and nitrogen isotope ratios (Bosley and Wainright 1999; Post 2002; Sarakinos et al. 2002; Fanelli et al. 2010; Ruiz-Cooley et al. 2011; Lau et al. 2012; Rennie et al. 2012; Liu et al. 2013) we acknowledge that the $\delta^{13} \mathrm{C}$ and $\delta^{15} \mathrm{~N}$ values of fauna from cold-water coral reefs may have been distorted due to the chosen method of sample preservation. The possible distortion of stable isotope 
ratios due to preservation in formalin could introduce some uncertainty in the examination of a community's trophic structure (i.e. carbon sources, species' trophic level); however, it should be mentioned that a) several studies have shown that the effects of formalin preservation on $\delta^{15} \mathrm{~N}$ values were minor compared to a commonly-used trophic fractionation factor (i.e. +3.4\%o, DeNiro and Epstein 1981; Post 2002) enabling thus the allocation of species to trophic levels (Fanelli et al. 2010) and b) a confounding effect on our findings should not be expected since both acidified and non-acidified subsamples have been preserved in formalin. Under these circumstances, we chose to address possible effects of formalin on $\delta^{13} \mathrm{C}$ values through the addition of $1 \%$, as in previous studies (Demopoulos et al. 2007; Sweetman and Witte 2008; Gontikaki et al. 2011; Hunter et al. 2012). This approach is in agreement with previous studies where a decrease up to $1 \%$ in $\delta^{13} \mathrm{C}$ values due to formalin preservation has been mentioned (Bosley and Wainright 1999; Edwards et al. 2002; Sarakinos et al. 2002; Syväranta et al. 2008; Bicknell et al. 2011; de Lecea et al. 2011; Xu et al. 2011; Lau et al. 2012; Rennie et al. 2012; Liu et al. 2013; González-Bergonzoni et al. 2015).

The species selected for bulk stable isotope analysis were: the cnidarian Parazoanthus anguicomus (Norman, 1868), the arthropods Aristias neglectus Hansen, 1888, Janira maculosa Leach, 1814, Galathea strigosa (Linnaeus, 1761), Scalpellum scalpellum (Linnaeus, 1767), the molluscs Asperarca nodulosa (juvenile) (O. F. Müller, 1776), cf Tonicella marmorea, the bryozoans Candidae sp., Chartella barleei (Busk, 1860), Reteporella beaniana (King, 1846), the echinoderms Ophiura ophiura (Linnaeus, 1758), Ophiothrix fragilis (Abildgaard, in O.F. Müller, 1789), Ophioctenella acies (adult and juveniles) Tyler et al. 1995, Porania (Porania) pulvillus (O.F. Müller, 1776) and the ascidian Polycarpa pomaria (Savigny, 1816). During expedition "2013 ArcticNet" on board the "CCGS Amundsen" megafauna samples from the east Canadian Arctic were collected using an Agassiz trawl at 5 stations in summer 2013. The stations were located in the Labrador Sea, Baffin Bay, North Water Polynya, Nares Strait and Lancaster Sound. The identification of specimens was feasible on board and thus it was followed by specimens' preservation at $-80^{\circ} \mathrm{C}$. Selected species included: the cnidarians Anthozoa indet., Umbellula sp., the arthropod Pagurus sp., the mollusc Margarites costalis (Gould, 1841), the echinoderms Gorgonocephalus sp., Ophiacantha bidentata (Bruzelius, 1805), Ophiopleura borealis Danielssen and Koren, 1877, Ctenodiscus crispatus (Retzius, 1805), Pontaster tenuispinus (Düben and Koren, 1846),
Psilaster andromeda (Müller and Troschel, 1842), Heliometra glacialis (Owen, 1833 ex Leach MS) and Strongylocentrotus droebachiensis (O.F. Müller, 1776).

\section{Sample preparation for stable isotope analysis}

Samples fixed in formalin were dried at $60^{\circ} \mathrm{C}$ while frozen samples were freeze-dried $\left(0.041 \mathrm{mbar},-49.8^{\circ} \mathrm{C}\right)$. The shell of the gastropod M. costalis was removed mechanically prior to grinding. However, carbonate removal was applied to the specimens of $M$. costalis due to the difficulty in removing all small shell pieces. Similarly, the shell of Pagurus sp. was removed before grinding. Grinding was carried out using the TissueLyser II (Qiagen) or a mortar and pestle according to the size of the organisms. Following grinding, each species was subjected to a preliminary analysis of their $\mathrm{C}$ and $\mathrm{N}$ content (as \% of dry mass) in order to assess the optimal amount of dry mass for dual $\left(\delta^{13} \mathrm{C}\right.$ and $\left.\delta^{15} \mathrm{~N}\right)$ stable isotope ratios analysis. Each sample of macro- and megafauna was divided in two subsamples i.e. subsamples to be acidified or not. Subsamples not to be acidified were placed in tin cups while subsamples to be acidified were placed in silver cups $(5 \times 8 \mathrm{~mm}$, Elemental Microanalysis UK). Carbonate removal was carried out through the sequential addition of $15 \mu \mathrm{l}$ of (1M) hydrochloric acid directly in the silver cups using a micropipette; the cessation of the effervescence was used as the criterion that carbonates had been removed (Vafeiadou et al. 2013). The total volume of $1 \mathrm{M}$ hydrochloric acid added in each silver cup was recorded (Table A2 in the Appendix). Both acidified and non-acidified samples were dried at $60^{\circ} \mathrm{C}$ overnight (e.g. Carabel et al. 2006; Jaschinski et al. 2008; Serrano et al. 2008); no washing with distilled water was carried out (Mateo et al. 2008). Overnight drying and no washing with distilled water were also performed for the non-acidified subsamples.

\section{Stable isotope analysis}

Samples from cold-water coral reefs were analysed for $\delta^{13} \mathrm{C}$ and $\delta^{15} \mathrm{~N}$ values at University of California Davis Stable Isotopes Facility (UC Davis SIF) using an Elementar Micro Cube Elemental Analyzer (Elementar Analysensysteme GmbH, Hanau, Germany) interfaced to a PDZ Europa 20-20 isotope ratio mass spectrometer (Sercon Ltd., Cheshire, UK). Samples were combusted at $1000^{\circ} \mathrm{C}$ in a reactor packed with tungsten oxide. During analysis, samples were interspersed with several replicates of at least five laboratory standards which had been previously calibrated against international isotope standards. The long term standard deviation is $0.2 \%$ for $\mathrm{C}$ and $0.3 \%$ for 
N isotopes. Samples from the Canadian Arctic were analysed for $\mathrm{C}$ and $\mathrm{N}$ isotopes at the James Hutton Institute (JHI, Aberdeen, UK) using a Flash EA 1112 Series Elemental Analyser connected via a Conflo III to a Delta ${ }^{\text {Plus }} \mathrm{XP}$ isotope ratio mass spectrometer (all Thermo Finnigan, Bremen, Germany). The isotope ratios were traceable to International Atomic Energy Agency reference materials USGS40 and USGS41 (both Lglutamic acid); certified both for $\delta^{13} \mathrm{C}\left(\% 0_{\mathrm{VPDB}}\right)$ and $\delta^{15} \mathrm{~N}$ $\left(\% o_{\text {air }}\right)$. Long term precisions for a quality control standard (milled flour) were: $\delta^{13} \mathrm{C}-25.5 \pm 0.2 \%$ and $\delta^{15} \mathrm{~N}+1.7 \pm 0.4 \%$ o (mean $\pm \mathrm{sd}, n=200$ ). The $\mathrm{C}$ and $\mathrm{N}$ content (as $\%$ of dry mass) was calculated based on the area output of the mass spectrometer and the dry mass (mg) analysed. The fact that samples were not preserved in the same way and they were analysed in different laboratories (Mill et al. 2008) does not have a confounding effect on results presented here since effects of carbonate removal were examined through comparisons between subsamples.

\section{Data treatment and statistical analysis}

The carbonate content of samples was determined through the carbonate proxy (CP) (Jacob et al. 2005). This proxy is based on the $\mathrm{C}: \mathrm{N}$ ratio (w:w) of acidified and non-acidified subsamples and is calculated through the following equation:

$$
\text { Carbonate proxy }=\frac{[C / N]_{\text {no acid }}}{[C / N]_{\text {acid }}}-1
$$

Statistical differences between acidified and non-acidified subsamples for the parameters $\% \mathrm{C}, \% \mathrm{~N}, \mathrm{C}: \mathrm{N}$ ratio, $\delta^{13} \mathrm{C}$, $\delta^{15} \mathrm{~N}$ were examined. The comparisons between acidified and non-acidified subsamples for the elemental and isotopic composition were carried out with the paired Student's $t$-test or non-parametric Wilcoxon signed rank-test (significance level $p<0.05$ ). Beforehand, the normality of the distributions was checked with the Shapiro-Wilk test and equality of variances with the F-test. The correlations between the $\mathrm{CP}$ and i) $\delta^{13} \mathrm{C}_{\text {no acid }} \delta^{13} \mathrm{C}_{\text {acid }}$ ii) $\delta^{15} \mathrm{~N}_{\text {no acid }} \delta^{15} \mathrm{~N}_{\text {acid }}$, were examined with Spearman's correlation $\left(r_{\mathrm{s}}\right)$. Examination of differences and correlations were carried out at the statistical analysis environment R. Only species with at least three replicates were included in the statistical analysis.

\section{Effects of carbonate removal on $\delta^{15} \mathrm{~N} \&$ trophic structure}

The effects of carbonate removal were further examined through the comparison of the trophic structure of a benthic community using $\delta^{15} \mathrm{~N}$ values from acidified and non-acidified samples. The benthic community that was examined is the recently-described association of the cold-water ecosystem engineer Spongosorites coralliophaga (Stephens, 1915) and its epifauna (Kazanidis et al. 2016) from cold-water coral reef settings at Mingulay reef complex (Mingulay reef hereafter; Outer Hebrides Sea, North-East Atlantic) and Logachev mound (Rockall Bank, North-East Atlantic) (Table A1 in Appendix). S. coralliophaga is a massive sponge that hosts a species-rich epifaunal community of more than 70 species (see Kazanidis et al. 2016 for details). This community is composed from four trophic levels both in Mingulay reef and Logachev mound (Kazanidis and Witte 2016). The trophic level of epifaunal species was calculated using $\delta^{15} \mathrm{~N}$ values from acidified and non-acidified sub-samples while the $\delta^{15} \mathrm{~N}$ values of two primary consumers (PC) were used as a trophic baseline. The following equation was used (following Iken et al. 2010):

$$
T P_{(P C)}=\left(\frac{\delta^{15} N_{\text {consumer }}-\delta^{15} N_{\text {primary-consumer }}}{3.4}\right)+2
$$

where $+3.4 \%$ is a commonly-used trophic fractionation factor for $\delta^{15} \mathrm{~N}$ between successive trophic levels (DeNiro and Epstein 1981; Minagawa and Wada 1984; Post 2002). Specifically, the trophic baselines used were the $\delta^{15} \mathrm{~N}$ values (acidified vs. non-acidified) from Parazoanthus anguicomus $\left(\delta^{15} \mathrm{~N}\right.$ values of non-acidified samples from Mingulay reef were $+8.6 \%$, $\delta{ }^{15} \mathrm{~N}$ values of acidified samples from Mingulay reef were $+8.5 \%$, $\delta^{15} \mathrm{~N}$ values of non-acidified samples from Logachev mound were $+8.5 \%$, $\delta^{15} \mathrm{~N}$ values of acidified samples from Logachev mound were $+8.3 \%$ ) and Reteporella beaniana $\left(\delta^{15} \mathrm{~N}\right.$ values of non-acidified samples from Mingulay reef were $+8.7 \%$, $\delta^{15} \mathrm{~N}$ values of acidified samples from Mingulay reef were $+7.3 \%$, $\delta^{15} \mathrm{~N}$ values of non-acidified samples from Logachev mound were $+9.1 \%, \delta^{15} \mathrm{~N}$ values of acidified samples from Logachev mound were $+7.8 \%$ ). The effects of carbonate removal on our perception about the trophic structure was examined in terms of a) number of trophic levels and b) species/ biomass distribution across the trophic levels (see Kazanidis and Witte 2016).

\section{Results and Discussion}

\section{Effects of carbonate removal on elemental composition}

In 14 taxa there was a statistically-significant decrease in their $\% \mathrm{C}$ (average values ranging from $-1.3 \pm 0.4$ in Margarites costalis to $-10.2 \pm 0.8$ in Ophiopleura borealis) while nonstatistically-significant shifts were found in 4 taxa (Table 1). 
Table 1. Effects of acidification (acidified minus non-acidified) on the elemental composition (\%C, \%N, C:N)

\begin{tabular}{|c|c|c|c|c|c|c|c|c|c|}
\hline Species & Phylum & $\mathrm{CP}$ & $\begin{array}{c}\text { \%C shift } \\
\text { (mean } \\
\pm \text { S.D) }\end{array}$ & $\begin{array}{c}\text { Paired } \\
\text { test }\end{array}$ & $\begin{array}{l}\text { \% N shift } \\
\text { (mean } \\
\pm \text { S.D) }\end{array}$ & $\begin{array}{c}\text { Paired } \\
\text { test }\end{array}$ & $\begin{array}{c}\text { C:N shift } \\
\text { (mean } \\
\pm \text { S.D) }\end{array}$ & $\begin{array}{c}\text { Paired } \\
\text { test }\end{array}$ & $\mathrm{n}$ \\
\hline Anthozoa indet. ${ }^{\mathrm{a}}$ & $\mathrm{CNI}$ & $0.3 \pm 0.1$ & $-5.5 \pm 1.7$ & $7.8^{\dagger}, * * *$ & $0.0 \pm 0.2$ & $0.4^{\dagger}, \mathrm{ns}$ & $-1.4 \pm 0.6$ & $6.2^{\dagger}, * *$ & 6 \\
\hline Parazoanthus anguicomus ${ }^{\mathrm{b}}$ & $\mathrm{CNI}$ & $0.2 \pm 0.1$ & $-2.6 \pm 2.8$ & $33^{\#}, *$ & $0.0 \pm 0.9$ & $18^{\#}, \mathrm{~ns}$ & $-0.6 \pm 0.5$ & $3.3^{\dagger}, *$ & 8 \\
\hline Umbellula sp. ${ }^{\mathrm{a}}$ & $\mathrm{CNI}$ & $0.2 \pm 0.0$ & $-5.1 \pm 0.9$ & NA & $-0.3 \pm 0.2$ & NA & $-0.7 \pm 0.0$ & NA & 2 \\
\hline Phylum average & $\mathrm{CNI}$ & $0.2 \pm 0.1$ & $-4.0 \pm 2.6$ & $133^{\#}, * * *$ & $-0.1 \pm 0.7$ & $0.4^{\dagger}, \mathrm{ns}$ & $-0.9 \pm 0.6$ & $224^{\#}, * * *$ & 16 \\
\hline Aristias neglectus $^{\mathrm{b}}$ & ART & $0.2 \pm 0.2$ & $-1.9 \pm 13.8$ & $0.7^{\dagger}, \mathrm{ns}$ & $+0.3 \pm 1.0$ & $-0.1^{\dagger}, \mathrm{ns}$ & $-0.5 \pm 1.5$ & $1.0^{\dagger}, \mathrm{ns}$ & 3 \\
\hline Galathea strigosa $^{\mathrm{b}}$ & ART & $0.1 \pm 0.2$ & $-1.8 \pm 3.8$ & $0.9^{\dagger}, \mathrm{ns}$ & $+0.4 \pm 0.6$ & $-1.2^{\dagger}, \mathrm{ns}$ & $-0.6 \pm 1.0$ & $1.4^{\dagger}, \mathrm{ns}$ & 4 \\
\hline Janira maculosa ${ }^{\mathrm{b}}$ & ART & 0.1 & -13.8 & NA & -2.6 & NA & -0.4 & NA & 1 \\
\hline Pagurus sp. ${ }^{\mathrm{a}}$ & ART & 0.1 & -4.4 & NA & -0.4 & NA & -0.4 & NA & 1 \\
\hline Scalpellum scalpellum $^{\mathrm{b}}$ & ART & 0.4 & -1.4 & NA & +0.8 & NA & -1.7 & NA & 2 \\
\hline Phylum average & ART & $0.2 \pm 0.2$ & $-4.2 \pm 7.9$ & $1.8^{\dagger}, \mathrm{ns}$ & $0.0 \pm 1.2$ & $-0.1^{\dagger}, \mathrm{ns}$ & $-0.9 \pm 1.0$ & $2.9^{\dagger}, *$ & 11 \\
\hline Asperarca nodulosa juv. ${ }^{\mathrm{b}}$ & MOL & 2.6 & -11.1 & NA & -0.3 & NA & -8.9 & NA & 1 \\
\hline Margarites costalis $^{\mathrm{a}}$ & MOL & $0.1 \pm 0.0$ & $-1.3 \pm 0.4$ & $6.2^{\dagger}, *$ & $+0.2 \pm 0.3$ & $-0.9^{\dagger}, \mathrm{ns}$ & $-0.2 \pm 0.1$ & $6^{\#}, \mathrm{~ns}$ & 3 \\
\hline cf Tonicella marmorea ${ }^{\mathrm{b}}$ & MOL & 0.0 & -19.8 & NA & -5.4 & NA & 0.0 & NA & 1 \\
\hline Phylum average & MOL & $0.6 \pm 1.1$ & $-7.0 \pm 8.3$ & $15^{\sharp}, \mathrm{ns}$ & $-1.1 \pm 2.5$ & $9.5^{\#}, \mathrm{~ns}$ & $-1.9 \pm 3.9$ & $10^{\#}, \mathrm{~ns}$ & 5 \\
\hline Candidae sp. ${ }^{\mathrm{b}}$ & BRY & $1.7 \pm 0.2$ & $-7.2 \pm 0.1$ & $124.7^{\dagger}, * * *$ & $+0.1 \pm 0.2$ & $-1.5^{\dagger}, \mathrm{ns}$ & $-6.3 \pm 1.0$ & $10.3^{\dagger}, * *$ & 3 \\
\hline Chartella barleei $^{\mathrm{b}}$ & BRY & $0.2 \pm 0.1$ & $-2.9 \pm 0.2$ & $25.1^{\dagger}, * *$ & $0.0 \pm 0.1$ & $-2.6^{\dagger}, \mathrm{ns}$ & $-0.8 \pm 0.3$ & $4.6^{\dagger} *$ & 3 \\
\hline Reteporella beaniana ${ }^{\mathrm{b}}$ & BRY & NA & NA & NA & $-0.1 \pm 0.2$ & $1^{\#}, \mathrm{~ns}$ & NA & NA & 3 \\
\hline Phylum average & $\overline{B R Y}$ & $0.9 \pm 0.8$ & $-5.0 \pm 2.4$ & $5.2^{\dagger}, * *$ & $0.0 \pm 0.2$ & $-0.2^{\dagger}, \mathrm{ns}$ & $-3.6 \pm 3.1$ & $2.8^{\dagger}, *$ & 9 \\
\hline Ctenodiscus crispatus $^{\mathrm{a}}$ & $\mathrm{ECH}$ & $0.8 \pm 0.4$ & $-9.1 \pm 1.4$ & $15.9^{\dagger}, * * *$ & $-0.4 \pm 0.4$ & $2.4^{\dagger}, \mathrm{ns}$ & $-3.1 \pm 1.1$ & $7.2^{\dagger}, * * *$ & 6 \\
\hline Gorgonocephalus sp. ${ }^{\mathrm{a}}$ & $\mathrm{ECH}$ & 1.0 & -7.6 & NA & -0.1 & NA & -3.7 & NA & 2 \\
\hline Heliometra glacialis ${ }^{\mathrm{a}}$ & $\mathrm{ECH}$ & $0.5 \pm 0.3$ & $-9.9 \pm 1.1$ & $20.6^{\dagger}, * * *$ & $-1.0 \pm 0.5$ & $4.3^{\dagger}, *$ & $-2.0 \pm 1.1$ & $4.2^{\dagger}, *$ & 5 \\
\hline Ophiacantha bidentata $^{\mathrm{a}}$ & $\mathrm{ECH}$ & $0.8 \pm 0.2$ & $-10.4 \pm 0.4$ & $10^{\#}, \mathrm{~ns}$ & $-0.8 \pm 0.3$ & $6.3^{\dagger}, * *$ & $-2.9 \pm 0.7$ & $7.9^{\dagger}, * *$ & 4 \\
\hline Ophioctenella acies ${ }^{\mathrm{b}}$ & $\mathrm{ECH}$ & $1.1 \pm 0.1$ & $-8.0 \pm 0.6$ & $22.6^{\dagger}, * *$ & $0.0 \pm 0.1$ & $0^{\dagger}, \mathrm{ns}$ & $-4.4 \pm 0.4$ & $6^{\#}, \mathrm{~ns}$ & 3 \\
\hline Ophioctenella acies juv. ${ }^{\mathrm{b}}$ & $\mathrm{ECH}$ & 1.4 & -7.9 & NA & +0.1 & NA & -5.6 & NA & 1 \\
\hline Ophiopleura borealis ${ }^{\mathrm{a}}$ & $\mathrm{ECH}$ & $1.1 \pm 0.7$ & $-10.2 \pm 0.8$ & $120^{\#}, * * *$ & $-0.6 \pm 0.4$ & $6.3^{\dagger}, * * *$ & $-4.3 \pm 2.4$ & $120^{\#}, * * *$ & 15 \\
\hline Ophiothrix fragilis ${ }^{\mathrm{b}}$ & $\mathrm{ECH}$ & $1.0 \pm 0.1$ & $-6.8 \pm 2.3$ & $5.0^{\dagger}, *$ & $+0.3 \pm 0.5$ & $-0.8^{\dagger}, \mathrm{ns}$ & $-4.4 \pm 0.8$ & $9.1^{\dagger}, *$ & 3 \\
\hline Ophiura ophiura & $\mathrm{ECH}$ & $0.7 \pm 0.2$ & $-9.4 \pm 2.8$ & $8.5^{\dagger}, * * *$ & $-0.4 \pm 0.5$ & $10^{\#}, \mathrm{~ns}$ & $-2.8 \pm 0.5$ & $12.8^{\dagger}, * * *$ & 6 \\
\hline Pontaster tenuispinus ${ }^{\mathrm{a}}$ & $\mathrm{ECH}$ & $0.8 \pm 0.7$ & $-10.1 \pm 1.2$ & $18.7^{\dagger}, * * *$ & $-0.9 \pm 0.6$ & $3.5^{\dagger}, *$ & $-3.2 \pm 2.4$ & $3.0^{\dagger}, *$ & 5 \\
\hline Porania pulvillus ${ }^{\mathrm{b}}$ & $\mathrm{ECH}$ & 0.9 & -7.3 & NA & +0.2 & NA & -2.9 & NA & 1 \\
\hline Psilaster andromeda ${ }^{\mathrm{a}}$ & $\mathrm{ECH}$ & $0.8 \pm 0.1$ & $-8.7 \pm 0.7$ & $21.1^{\dagger}, * *$ & $-0.3 \pm 0.1$ & $5.2^{\dagger}, *$ & $-2.9 \pm 0.3$ & $6^{\#}, \mathrm{~ns}$ & 3 \\
\hline Strongylocentrotus droebachiensis ${ }^{\mathrm{a}}$ & $\mathrm{ECH}$ & $1.3 \pm 0.4$ & $-9.0 \pm 0.7$ & $27.1^{\dagger}, * * *$ & $-0.3 \pm 0.2$ & $10^{\#}, \mathrm{~ns}$ & $-5.0 \pm 1.0$ & $11.1^{\dagger}, * * *$ & 5 \\
\hline Phylum average & $\mathrm{ECH}$ & $0.9 \pm 0.5$ & $-9.4 \pm 1.6$ & $1770^{\#}, * * *$ & $-0.5 \pm 0.5$ & $7.5^{\dagger}, * * *$ & $-3.6 \pm 1.7$ & $1770^{\#}, * * *$ & 59 \\
\hline Polycarpa pomaria ${ }^{\mathrm{b}}$ & $\mathrm{CHO}$ & $0.0 \pm 0.1$ & $-0.2 \pm 1.7$ & $10^{\#}, \mathrm{~ns}$ & $0.0 \pm 0.5$ & $6^{\#}, \mathrm{~ns}$ & $0.0 \pm 0.7$ & $10^{\#}, \mathrm{~ns}$ & 5 \\
\hline
\end{tabular}

${ }^{a}$ Arctic; ${ }^{b}$ cold-water coral reefs; $n$ : number of replicates; Carbonate proxy (CP); cnidarians (CNI); arthropods (ART); molluscs (MOL); bryozoans (BRY); echinoderms (ECH); chordata (CHO). Mean values, standard deviations (S.D), results of statistical test ("parametric paired $t$-test; ${ }^{*}$ nonparametric paired Wilcoxon test) and $P$ values $(* * * P \leq 0.001, * * 0.001<P \leq 0.01, * 0.01<P \leq 0.05$, ns: no significant) are given

The highest decreases in $\% \mathrm{C}$ were found in echinoderms $(-9.4$ $\pm 1.6, P<0.001)$ and bryozoans $(-5.0 \pm 2.4, P<0.01)$ (i.e. in organisms with carbonate proxy values higher than +0.5$)$. In a previous study by Serrano et al. (2008) on beach arthropods the decrease in $\% \mathrm{C}$ was attributed to the loss of both inorganic (i.e. carbonates) and organic carbon after carbonate removal. Loss of organic carbon may have also played a role in the $\% \mathrm{C}$ decrease in species with low carbonate content and especially in the isopod Janira maculosa and the chiton cf Tonicella marmorea where the decrease in $\% \mathrm{C}$ was comparable to that found in echinoderms (Table 1). For those species with high carbonate content (e.g. echinoderms, calcified bryozoans; average $\mathrm{CP}$ values +0.9 in both Phyla; Table 1$)$ it is suggested that the significant decrease $(P<0.01)$ in \%C was driven by the removal of carbonates.

As regards $\% \mathrm{~N}$, echinoderms were the only group where a 
statistically-significant decrease was found (i.e. 5 out of 19 species, average values ranging from $-0.3 \pm 0.1$ in Psilaster andromeda to $-1.0 \pm 0.5$ in Heliometra glacialis). Based on this, we recommend that future studies examining $\% \mathrm{~N}$ in heavily-calcified species should avoid the acid pre-treatment of samples to avoid any miscalculations of $\% \mathrm{~N}$ and C:N ratios. Non statistically-significant shifts were found in 14 out of the 19 taxa (Table 1). In the arthropods Aristias neglectus, Galathea strigosa, the mollusc Margarites costalis and the echinoderm Ophiothrix fragilis there was a non-significant increase $(P>$ $0.05)$ in their $\% \mathrm{~N}$, which was probably due to the preferential removal of organic compounds depleted in nitrogen content (Bunn et al. 1995). The absence of a uniform trend regarding the effects of carbonate removal on $\% \mathrm{~N}$ is in agreement with previous studies which have revealed a decrease (Serrano et al. 2008), an increase (Bunn et al. 1995) or no significant impact (Mazumder et al. 2010).

In $67 \%$ of the species, there was a statistically-significant decrease in the C:N ratio, which shows a proportionally-higher loss of carbon than nitrogen (Table 1) as well as the differences between carbon and nitrogen as regards their response to carbonate removal using hydrochloric acid. The decrease in the $\mathrm{C}: \mathrm{N}$ ratio was higher in heavily-calcified species i.e. calcified bryozoans and echinoderms $(-3.6 \%)$ than lightlycalcified species i.e. cnidarians and arthropods $(-0.9 \%)$. The proportionally higher loss of carbon than nitrogen in the heavilycalcified species played a major role in the formulation of their high CP values; specifically, the $\mathrm{CP}$ values in echinoderms and bryozoans were among the highest that have been recorded up to now in marine invertebrates (Jacob et al. 2005; $\mathrm{Ng}$ et al. 2007; Kolasinski et al. 2008; Serrano et al. 2008).

The mean $\mathrm{CP}$ values in the vast majority of species were positive; however, a small number of samples (3 out of 102) showed negative values. Interestingly in Aristias neglectus $(\mathrm{CP}=-0.1)$, Galathea strigosa $(\mathrm{CP}=-0.1)$ and Polycarpa pomaria $(\mathrm{CP}=-0.2)$ the negative $\mathrm{CP}$ was due to an increase in the acidified subsamples of the $\% \mathrm{C}$ accompanied by an increase or decrease in $\% \mathrm{~N}$. In previous studies negative $\mathrm{CP}$ values were attributed to a proportionally higher loss of $\% \mathrm{~N}$ than $\% \mathrm{C}$ in the acidified subsamples (Jacob et al. 2005; Kolasinski et al. 2008; Serrano et al. 2008); however, here it is shown that negative $\mathrm{CP}$ can also arise through alternative pathways [i.e. increase in $\% \mathrm{C}$ and $\% \mathrm{~N}$ in acidified subsamples through loss of molecules comparatively low in $\% \mathrm{C}$ and $\% \mathrm{~N}$ (Bunn et al. 1995) or decrease in $\% \mathrm{~N}$ through the volatilization of organic compounds (King et al. 1998; Lohse et al. 2000;
Serrano et al. 2008)]. This indicates that the CP should be used mainly with heavily-calcified species whereas in the lightly-calcified ones it should be used with caution. While the CP may not always represent the effects of carbonate removal on carbonates, it can sometimes reveal the effects on organic carbon and nitrogen (see also Serrano et al. 2008).

\section{Effects of carbonate removal on isotopic composition}

In 10 taxa there was a statistically-significant decrease in their $\delta^{13} \mathrm{C}$ (average values ranging from $-3.6 \pm 2.0$ in Anthozoa indet. to $-10.5 \pm 1.2$ in the bryozoan Candidae sp.) while nonstatistically-significant shifts were found in 8 taxa (Table 2). The highest decreases in $\delta^{13} \mathrm{C}$ were found in bryozoans (-6.7 $\pm 4.4, P<0.01$ ) (Fig. $1 \mathrm{~g}$ ) and echinoderms $(-8.1 \pm 2.8, P<0.001)$ (Fig. 1i) i.e. in organisms with carbonate proxy values higher than +0.5 and the least decreases in cnidarians $(-2.4 \pm 2.1, P<$ 0.001) (Fig. 1a; Table 2). Shifts in $\delta^{13} \mathrm{C}$ values recorded in the present study (i.e. up to - $14.7 \%$ in Asperarca nodulosa) (Fig. 1e) are -to the best of our knowledge- the highest ones that have been recorded up to now between acidified and nonacidified subsamples from marine invertebrates (Schlacher and Connolly 2014 and references therein). In Parazoanthus anguicomus, Aristias neglectus and Chartella barleei there were not significant differences in $\delta^{13} \mathrm{C}$ between acidified and non-acidified subsamples $(-1.4 \pm 2.1, P=0.09,+0.7 \pm 0.5$, $P=0.25$ and $-2.8 \pm 1.8, P=0.25$, respectively) but the mean shift in their $\delta^{13} \mathrm{C}$ exceeded the range of $+0.5 \%$ to $+1.0 \%$, which is regarded as the shift between consumers and their prey (Post 2002; McCutchan et al. 2003). Similarly, the asteroid Pontaster tenuispinus did not show significant differences between acidified and non-acidified $\delta^{13} \mathrm{C}$ values; however, this result should be treated with caution since the $P$-value $(0.06)$ was marginally higher than 0.05 . Based on our findings about the absence of statistically-significant shifts in $\delta^{13} \mathrm{C}$ values in those species mentioned above, we recommend that researchers should be careful about omitting carbonate removal in lightlycalcified species (see also Yokoyama et al. 2005; Vafeiadou et al. 2013).

As regards the effects of carbonate removal on $\delta^{15} \mathrm{~N}$, there were statistically-significant shifts in 5 out of the 19 taxa ranging from $-0.4 \pm 0.3 \%$ in the ascidian Polycarpa pomaria $(P<0.05)$ to $-0.8 \pm 0.6 \%$ in the sea urchin Strongylocentrotus droebachiensis $(P<0.05)$. In two species (i.e. the echinoderms Ophiacantha bidentata and Ophiopleura borealis), the significant decrease in $\delta^{15} \mathrm{~N}$ was accompanied by a significant decrease in $\% \mathrm{~N}$; it is possible that the high volume of hydrochloric 
Table 2. Effects of acidification (acidified minus non-acidified) on $\delta^{13} \mathrm{C}, \delta^{15} \mathrm{~N}$

\begin{tabular}{|c|c|c|c|c|c|c|c|}
\hline Species & Phylum & $\mathrm{CP}$ & $\begin{array}{c}\delta^{13} \mathrm{C} \text { shift } \\
(\text { mean } \pm \text { S.D })\end{array}$ & $\begin{array}{l}\text { Paired } \\
\text { test }\end{array}$ & $\begin{array}{c}\delta^{15} \mathrm{~N} \text { shift } \\
(\text { mean } \pm \text { S.D })\end{array}$ & $\begin{array}{c}\text { Paired } \\
\text { test }\end{array}$ & $\mathrm{n}$ \\
\hline Anthozoa indet. ${ }^{\mathrm{a}}$ & $\mathrm{CNI}$ & $+0.3 \pm 0.1$ & $-3.6 \pm 2.0$ & $4.4^{\dagger}, * *$ & $-0.2 \pm 0.4$ & $1.7^{\dagger}, \mathrm{ns}$ & 6 \\
\hline Parazoanthus anguicomus ${ }^{\mathrm{b}}$ & $\mathrm{CNI}$ & $+0.2 \pm 0.1$ & $-1.4 \pm 2.1$ & $1.9^{\dagger}, \mathrm{ns}$ & $-0.2 \pm 0.4$ & $1.7^{\dagger}, \mathrm{ns}$ & 8 \\
\hline Umbellula sp. ${ }^{\mathrm{a}}$ & $\mathrm{CNI}$ & $+0.2 \pm 0.0$ & -2.3 & NA & -1.1 & NA & 2 \\
\hline Phylum average & $\mathrm{CNI}$ & $+0.2 \pm 0.1$ & $-2.4 \pm 2.1$ & $133^{\#}, * * *$ & $-0.3 \pm 0.5$ & $117.5^{\#}, *$ & 16 \\
\hline Aristias neglectus $^{\mathrm{b}}$ & ART & $+0.2 \pm 0.2$ & $+0.7 \pm 0.5$ & $0^{\#}, \mathrm{~ns}$ & $+0.3 \pm 0.5$ & $-0.6^{\dagger}, \mathrm{ns}$ & 3 \\
\hline Galathea strigosa ${ }^{\mathrm{b}}$ & ART & $+0.1 \pm 0.2$ & $-0.4 \pm 1.5$ & $0.5^{\dagger}, \mathrm{ns}$ & $0.0 \pm 0.4$ & $-0.1^{\dagger}, \mathrm{ns}$ & 4 \\
\hline Janira maculosa ${ }^{\mathrm{b}}$ & ART & +0.1 & +0.6 & NA & 0.0 & NA & 1 \\
\hline Pagurus sp. ${ }^{\mathrm{a}}$ & ART & +0.1 & -1.8 & NA & 0.0 & NA & 1 \\
\hline Scalpellum scalpellum $^{\mathrm{b}}$ & ART & +0.4 & $-6.6 \pm 2.0$ & NA & $-0.8 \pm 0.8$ & NA & 2 \\
\hline Phylum average & ART & $+0.2 \pm 0.2$ & $-1.3 \pm 2.9$ & $1.4^{\dagger}, \mathrm{ns}$ & $-0.1 \pm 0.6$ & $0.3^{\dagger}, \mathrm{ns}$ & 11 \\
\hline Asperarca nodulosa juv. ${ }^{b}$ & MOL & +2.6 & -14.7 & NA & -0.3 & NA & 1 \\
\hline Margarites costalis $^{\mathrm{a}}$ & MOL & $+0.1 \pm 0.0$ & $-0.1 \pm 0.2$ & $1^{\dagger}, \mathrm{ns}$ & $-0.7 \pm 0.1$ & $9.5^{\dagger}, *$ & 3 \\
\hline cf Tonicella marmorea ${ }^{\mathrm{b}}$ & MOL & 0.0 & -1.2 & NA & -0.4 & NA & 1 \\
\hline Phylum average & MOL & $+0.6 \pm 1.1$ & $-3.2 \pm 6.4$ & $6^{\#}, \mathrm{~ns}$ & $-0.5 \pm 0.2$ & $6.5^{\dagger}, * *$ & 5 \\
\hline Candidae sp. ${ }^{\mathrm{b}}$ & BRY & $+1.7 \pm 0.2$ & $-10.5 \pm 1.2$ & $14.4^{\dagger}, * *$ & $-0.3 \pm 0.1$ & $3.0^{\dagger}, \mathrm{ns}$ & 3 \\
\hline Chartella barleei $^{\mathrm{b}}$ & BRY & $+0.2 \pm 0.1$ & $-2.8 \pm 1.8$ & $6^{\#}, \mathrm{~ns}$ & $-0.3 \pm 0.2$ & $2.8^{\dagger}, \mathrm{ns}$ & 3 \\
\hline Reteporella beaniana ${ }^{\mathrm{b}}$ & BRY & NA & NA & NA & $-1.4 \pm 0.8$ & $2.8^{\dagger}, \mathrm{ns}$ & 3 \\
\hline Phylum average & BRY & $+0.9 \pm 0.8$ & $-6.7 \pm 4.4$ & $36^{\#}, * *$ & $-0.7 \pm 0.7$ & $2.8^{\dagger}, *$ & 9 \\
\hline$\overline{\text { Ctenodiscus crispatus }}^{\mathrm{a}}$ & $\mathrm{ECH}$ & $+0.8 \pm 0.4$ & $-6.4 \pm 1.6$ & $9.6^{\dagger}, * * *$ & $-0.3 \pm 0.4$ & $1.4^{\dagger}, \mathrm{ns}$ & 6 \\
\hline Gorgonocephalus sp. ${ }^{\mathrm{a}}$ & $\mathrm{ECH}$ & +1.0 & $-8.4 \pm 0.8$ & NA & $-0.4 \pm 0.3$ & NA & 2 \\
\hline Heliometra glacialis ${ }^{\mathrm{a}}$ & $\mathrm{ECH}$ & $+0.5 \pm 0.3$ & $-4.6 \pm 1.4$ & $7.4^{\dagger}, * *$ & $-0.3 \pm 0.4$ & $10^{\#}, \mathrm{~ns}$ & 5 \\
\hline Ophiacantha bidentata $^{\mathrm{a}}$ & $\mathrm{ECH}$ & $+0.8 \pm 0.2$ & $-9.2 \pm 0.6$ & $32.5^{\dagger}, * * *$ & $-0.5 \pm 0.2$ & $4.6^{\dagger}, *$ & 4 \\
\hline Ophioctenella acies ${ }^{\mathrm{b}}$ & $\mathrm{ECH}$ & $+1.1 \pm 0.1$ & $-10.2 \pm 0.9$ & $18.9^{\dagger}, * *$ & $-0.1 \pm 0.5$ & $4^{\#}, \mathrm{~ns}$ & 3 \\
\hline Ophioctenella acies juv. ${ }^{\mathrm{b}}$ & $\mathrm{ECH}$ & +1.4 & -12.1 & NA & -0.3 & NA & 1 \\
\hline Ophiopleura borealis ${ }^{\mathrm{a}}$ & $\mathrm{ECH}$ & $+1.1 \pm 0.7$ & $-9.6 \pm 2.7$ & $13.8^{\dagger}, * * *$ & $-0.5 \pm 0.3$ & $7.1^{\dagger}, * * *$ & 15 \\
\hline Ophiothrix fragilis ${ }^{\mathrm{b}}$ & $\mathrm{ECH}$ & $+1.0 \pm 0.1$ & $-10.7 \pm 1.8$ & $6^{\#}, \mathrm{~ns}$ & $-0.6 \pm 0.6$ & $1.8^{\dagger}, \mathrm{ns}$ & 3 \\
\hline Ophiura ophiura ${ }^{\mathrm{b}}$ & $\mathrm{ECH}$ & $+0.7 \pm 0.2$ & $-6.6 \pm 1.5$ & $10.8^{\dagger}, * * *$ & $+0.3 \pm 0.6$ & $-1.1^{\dagger}, \mathrm{ns}$ & 6 \\
\hline Pontaster tenuispinus $^{\mathrm{a}}$ & $\mathrm{ECH}$ & $+0.8 \pm 0.7$ & $-7.6 \pm 2.1$ & $15^{\#}, \mathrm{~ns}$ & $-0.2 \pm 0.5$ & $1.3^{\dagger}, \mathrm{ns}$ & 5 \\
\hline Porania pulvillus ${ }^{\mathrm{b}}$ & $\mathrm{ECH}$ & +0.9 & -3.2 & NA & -0.4 & NA & 1 \\
\hline Psilaster andromeda ${ }^{\mathrm{a}}$ & $\mathrm{ECH}$ & $+0.8 \pm 0.1$ & $-4.0 \pm 0.5$ & $13.9^{\dagger}, * *$ & $-0.8 \pm 0.3$ & $6^{\#}, \mathrm{~ns}$ & 3 \\
\hline Strongylocentrotus droebachiensis ${ }^{\mathrm{a}}$ & $\mathrm{ECH}$ & $+1.3 \pm 0.4$ & $-10.4 \pm 1.5$ & $15.7^{\dagger}, * * *$ & $-0.8 \pm 0.6$ & $2.9^{\dagger} *$ & 5 \\
\hline Phylum average & $\mathrm{ECH}$ & $+0.9 \pm 0.5$ & $-8.1 \pm 2.8$ & $1770^{\#}, * * *$ & $-0.4 \pm 0.5$ & $1482^{\#}, * * *$ & 59 \\
\hline Polycarpa pomaria ${ }^{\mathrm{b}}$ & $\mathrm{CHO}$ & $+0.0 \pm 0.1$ & $-0.1 \pm 0.4$ & $0.9^{\dagger}, \mathrm{ns}$ & $-0.4 \pm 0.3$ & $3.6^{\dagger}, *$ & 5 \\
\hline
\end{tabular}

${ }^{a}$ Arctic; ${ }^{b}$ cold- water coral reefs; $n$ : number of replicates. Carbonate proxy (CP); cnidarians (CNI); arthropods (ART); molluscs (MOL); bryozoans (BRY); echinoderms (ECH); chordata (CHO). Mean values, standard deviations (S.D), results of statistical test ("parametric paired $t$-test; ${ }^{*}$ nonparametric paired Wilcoxon test) and $P$ values $(* * * P \leq 0.001, * * 0.001<P \leq 0.01, * 0.01<P \leq 0.05$, ns: no significant) are given

acid added until the cessation of the effervescence (i.e. approx. $200 \mu$, see Table A2 in Appendix) caused a substantial loss of organic nitrogen. On the other hand, the significant decrease in the $\delta^{15} \mathrm{~N}$ of the three others (i.e. the ascidian Polycarpa pomaria, the mollusc Margarites costalis and the sea urchin Strongylocentrotus droebachiensis) was not followed by a significant decrease in their $\% \mathrm{~N}$. This is particularly interesting for P.pomaria and M. costalis since the volume of hydrochloric acid added for their carbonate removal (average values were
60 and $40 \mu$, respectively) was much smaller than the amount used for the carbonate removal in species whose $\delta^{15} \mathrm{~N}$ values were not significantly affected by carbonate removal (e.g. the bryozoan Candidae sp., the echinoderm Psilaster andromeda) (see Table A2 in Appendix for hydrochloric acid added in each species and Table 2 in main text for shifts in $\delta^{15} \mathrm{~N}$ values). It is possible that the loss of a small amount of organic nitrogencontaining compounds with enriched $\delta^{15} \mathrm{~N}$ values contributed to the findings for these two species (see also Goering et al. 

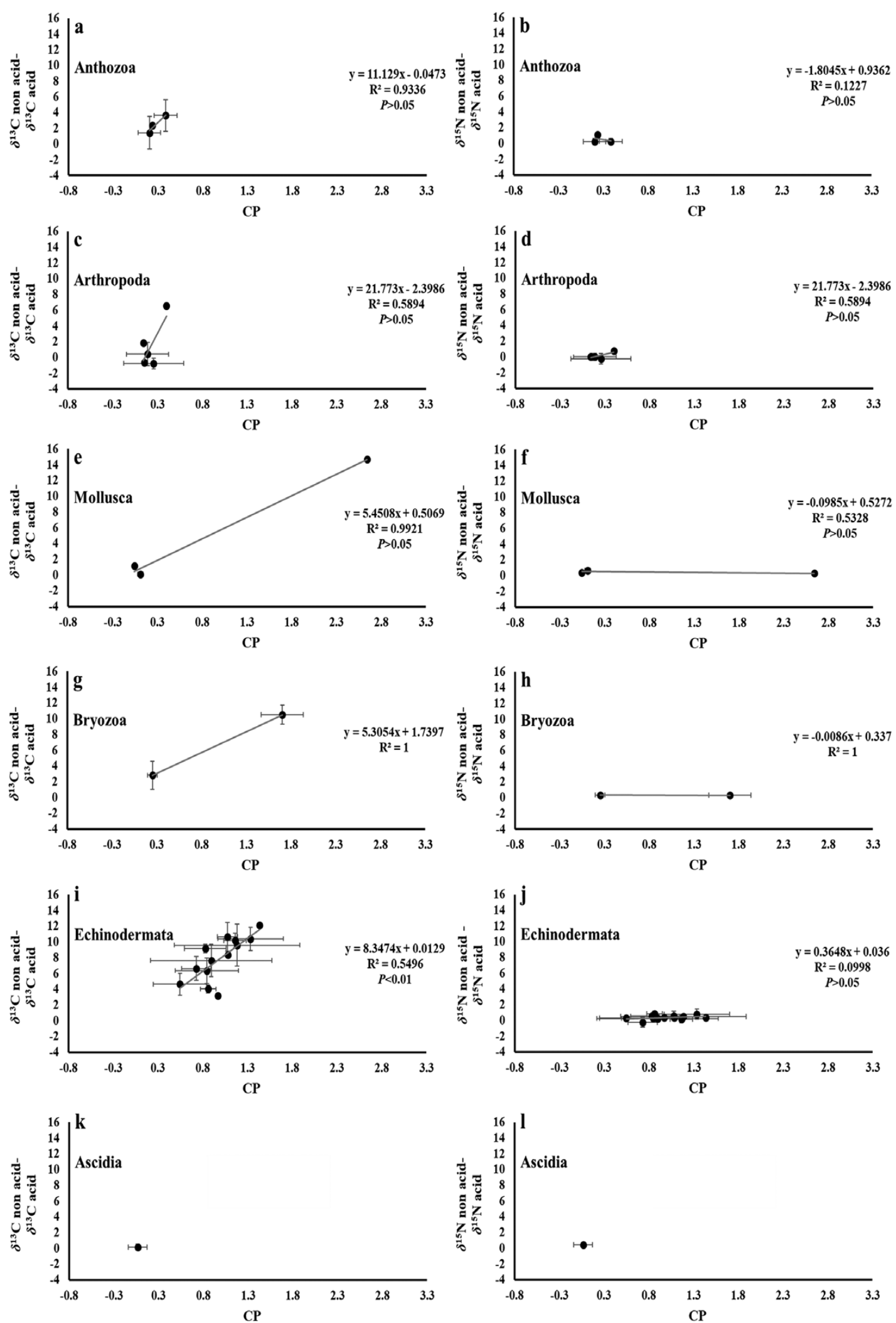

Fig. 1. (a, c, e, g, i, k) Relationship between the carbonate proxy $(\mathrm{CP})$ and the shift in $\delta^{13} \mathrm{C}$ values between acidified and non-acidified subsamples for each of the taxonomic groups; $(b, d, f, h, j, 1)$. Relationship between the carbonate proxy (CP) and the shift in $\delta^{15} \mathrm{~N}$ values between non-acidified and acidified subsamples for each of the taxonomic groups. Mean values, standard deviations, correlation coefficients $\left(R^{2}\right)$ and $P$ values are given

\section{Springer}


1990; Wolf et al. 2009).

There was no relationship between the carbonate proxy (CP) and shifts in $\delta^{15} \mathrm{~N}$ (Figs. 1b for anthozoans; 1d for arthropods; $1 \mathrm{f}$ for molluscs; $1 \mathrm{j}$ for echinoderms). These results are in agreement with previous findings about arthropods (Bosley and Wainright 1999; Fantle et al. 1999; Yokoyama et al. 2005; Carabel et al. 2006; Serrano et al. 2008; but see also Bunn et al. 1995) and various invertebrates from a tropical reef(Kolasinski et al. 2008) and from seagrass beds (Jaschinski et al. 2008; Vafeiadou et al. 2013).

\section{Effects of carbonate removal on the interpretation of trophic structure}

Studies on trophic structure of marine communities often use the $\delta^{15} \mathrm{~N}$ values of suspended or sedimented particulate organic matter as a trophic baseline (e.g. Grall et al. 2006; Iken et al. 2010; Divine et al. 2015). However, the high variability in the $\delta^{15} \mathrm{~N}$ values of primary producers introduces substantial variability in the calculations of the trophic level of species and comparisons of trophic structure between areas (Cabana and Rasmussen 1996; Vander Zanden and Rasmussen 1999; Post 2002; Vander Zanden and Fetzer 2007; Iken et al. 2010).

In the present study, the use of $\delta^{15} \mathrm{~N}$ values from acidified subsamples from primary consumers resulted in miscalculations for the number of trophic levels, distribution of species and distribution of biomass across the trophic levels. Specifically, at Mingulay reef, the use of $\delta^{15} \mathrm{~N}$ values from acidified subsamples from Reteporella beaniana as a baseline increased the number of trophic levels from four to five (Fig. 2a and b). This was due to the decrease of $R$. beaniana's $\delta^{15} \mathrm{~N}$ value from $+8.7 \%$ in non-acidified subsamples $(n=1)$ to $+7.3 \%$ in acidified subsamples $(n=1)$. The use of $\delta^{15} \mathrm{~N}$ values from acidified subsamples of $R$. beaniana resulted in miscalculations also in Logachev mound. Specifically, the use of acidified subsamples resulted in a higher number of species and higher biomass in

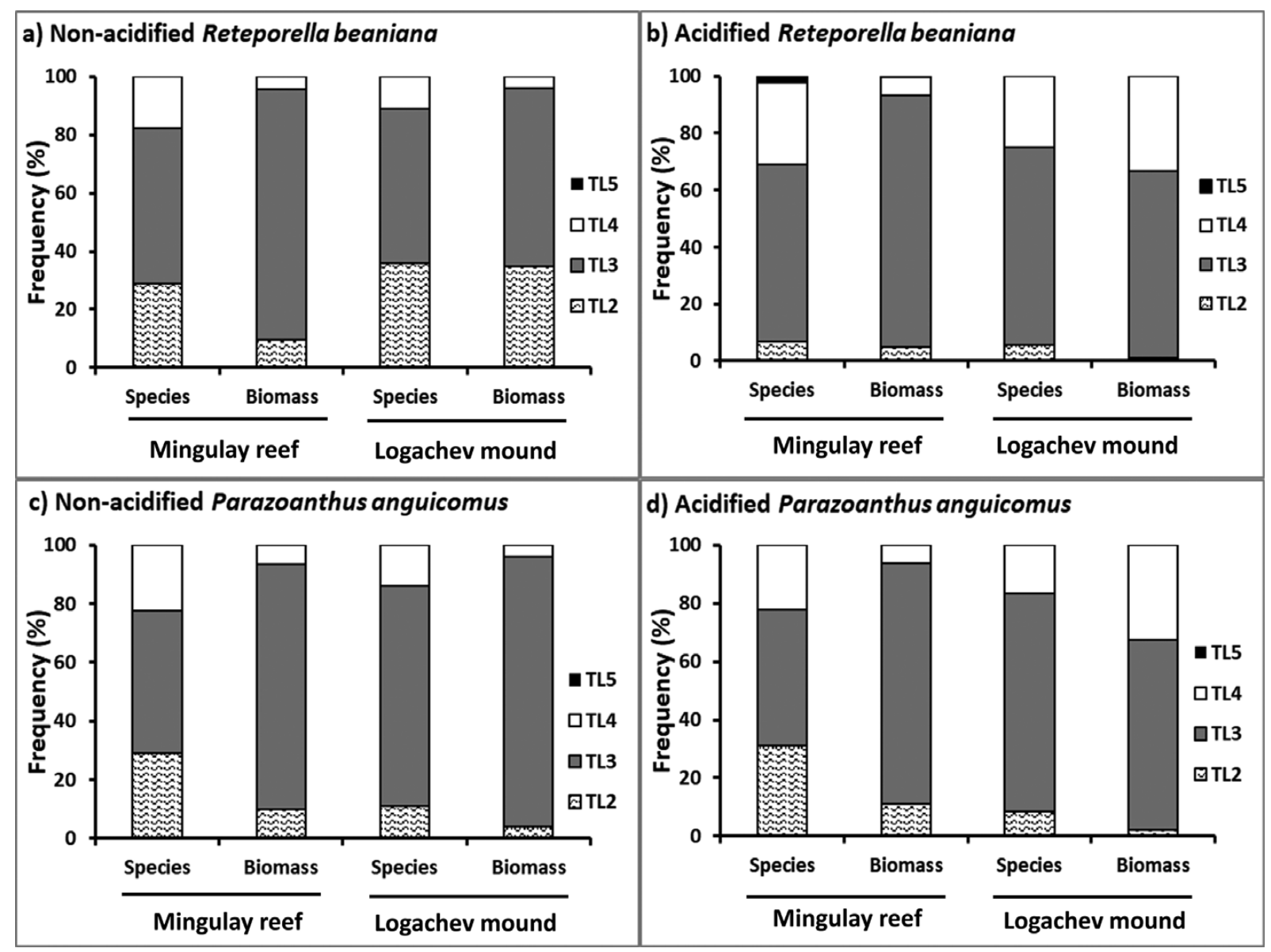

Fig. 2. Distribution (expressed as frequency \%) of species and biomass across trophic levels (TL) using as a trophic baseline the $\delta^{15} \mathrm{~N}$ value of non-acidified and acidified specimens of the bryozoan Reteporella beaniana (a, b) and non-acidified and acidified specimens of the anthozoan Parazoanthus anguicomus (c, d) from Mingulay reef and Logachev mound 
the third and fourth trophic levels. This was due to the decrease in the $\delta^{15} \mathrm{~N}$ from $+9.1(n=2)$ in non-acidified subsamples to $+7.8 \%$ in acidified subsamples ( $n=2$ ) (Fig. $2 \mathrm{a}$ and b). In contrast to findings for $R$. beaniana, the use of $\delta^{15} \mathrm{~N}$ values from acidified subsamples of Parazoanthus anguicomus as a baseline did not lead to miscalculations about the number of trophic levels, the distribution of species and the distribution of biomass across the trophic levels (Fig. 2c and d). This is because the acid treatment had a smaller impact on the $\delta^{15} \mathrm{~N}$ values of $P$. anguicomus than $R$. beaniana (see Table 2 for details).

The findings described above provided evidence that the use of $\delta^{15} \mathrm{~N}$ values from acidified subsamples as a trophic baseline can alter substantially our perception about the trophic structure of a community. In our case this was due to the miscalculation (underestimation) of the trophic baseline when $\delta^{15} \mathrm{~N}$ values from acidified $R$. beaniana were used. Taking these findings into account it is likely that the use of $\delta^{15} \mathrm{~N}$ values from acidified specimens in previous studies (e.g. Mintenbeck et al. 2007; Yokoyama et al. 2009; Iken et al. 2010; Feder et al. 2011; Sokolowski et al. 2014; Divine et al. 2015; Tu et al. 2015) may have introduced some bias in the assessment of community trophic structure.

\section{Conclusions and recommendations for future work}

The present study showed that the removal of carbonates through acid pre-treatment can modify the elemental and isotopic composition of both lightly- and heavily-calcified marine invertebrates. Apart from the removal of carbonates, acid pre-treatment removed also organic carbon and nitrogen. This loss of organic matter affected the carbonate proxy (CP) values, thus confounding the interpretation of species' $\mathrm{CP}$. Based on our findings we recommend that this proxy should be used with heavily-calcified species.

Furthermore, the present study provided evidence that the use of $\delta^{15} \mathrm{~N}$ values from acidified samples can introduce substantial bias in our perception about the trophic structure of a community. This is the first time that the effects of acid pre-treatment are examined within such a framework and the results of our analysis should be taken seriously into account in future food-web studies.

The effects of carbonate removal varied among Phyla with heavily-calcified organisms like echinoderms and calcified bryozoans being the most affected in terms of carbon content $(\% \mathrm{C})$ and $\delta^{13} \mathrm{C}$. On the other hand, we did not detect such a trend for nitrogen content $(\% \mathrm{~N})$ and $\delta^{15} \mathrm{~N}$. The different sensitivity to carbonate removal between elements and among taxonomic groups, and thus the difficulties arising in predicting the shifts in elemental and isotopic composition following acid pre-treatment, should be taken into account in future ecological and biogeochemical works studying the elemental $\left(\% \mathrm{C}, \% \mathrm{~N}, \mathrm{C}: \mathrm{N}\right.$ ratio) and isotopic composition $\left(\delta^{13} \mathrm{C}, \delta^{15} \mathrm{~N}\right)$ of marine invertebrates. This will contribute to the optimum use of available samples and prevent bias in the interpretation of findings.

\section{Acknowledgments}

Special thanks to captains, crews and science parties of the RRS James Cook (JC073 Changing Oceans Expedition) and the CCGS Amundsen (2013 ArcticNet Expedition). Thanks also to the Holland-I ROV team (JC073 Changing Oceans Expedition). Thanks to Anni Makela (University of Aberdeen) and Cindy Grant (University of ISMER) for sampling of the megafauna. Also thanks to Dr Evina Gontikaki (University of Aberdeen) for her guidance on sample preparation for isotope analysis, Kenneth Cruickshank (University of Aberdeen) for analysis on sample elemental composition, Dr Joy Matthews, Sylvia Duncan and Emily Schick at UC Davis Stable Isotope Facility and Barry Thornton and Gillian Martin from the James Hutton Institute for their co-operation on sample stable isotope analysis. Funding for the JC073 cruise was provided by the Natural Environment Research Council (NERC) UK Ocean Acidification (UKOA) research programme's Benthic Consortium project (NE/H017305/1 to J Murray Roberts). Funding for participation in the Arctic crusie with CCGS Amundsen was provided by NERC funded research project ArcDEEP (NE/J023094/1 to Ursula Witte). Funding for analytical costs and field work was provided by the Marine Alliance for Science and Technology for Scotland (MASTS) (Biodiversity Grant to Ursula Witte, 140 SF10003-10) and ArcDEEP (NERC grant NE/J023094/1). Georgios Kazanidis was funded by a MASTS PhD scholarship and S. Bourgeois by the NERC ArcDEEP project.

\section{Open Access}

This article is distributed under the terms of the Creative Commons Attribution 4.0 International License (http:// creativecommons.org/licenses/by/4.0/), which permits unrestricted use, distribution, and reproduction in any medium, provided you give appropriate credit to the original author(s) and the source, provide a link to the Creative Commons license, and 
indicate if changes were made.

\section{References}

Bicknell AWJ, Campbell M, Knight ME, Bilton DT, Newton J, Votier SC (2011) Effects of formalin preservation on stable carbon and nitrogen isotope signatures in calanoid copepods: implications for the use of Continuous Plankton Recorder Survey samples in stable isotope analyses. Rapid Commun Mass Sp 25:1794-1800. doi:10.1002/rcm.5049

Bosley KL, Wainright SC (1999) Effects of preservatives and acidification on the stable isotope ratios $\left({ }^{15} \mathrm{~N}:{ }^{14} \mathrm{~N},{ }^{13} \mathrm{C}:{ }^{12} \mathrm{C}\right)$ of two species of marine animals. Can J Fish Aquat Sci 56:21812185

Brodie CR, Leng MJ, Casford JSL, Kendrick CP, Lloyd JM, Yongqiang Z, Bird MI (2011) Evidence for bias in C and N concentrations and $\delta^{13} \mathrm{C}$ composition of terrestrial and aquatic organic materials due to pre-analysis acid preparation methods. Chem Geol 282:67-83. doi:10.1016/j.chemgeo.2011.01.007

Bunn SE, Loneragan NR, Kempster MA (1995) Effects of acid washing on stable isotope ratios of $\mathrm{C}$ and $\mathrm{N}$ in penaeid shrimp and seagrass: implications for food web studies using multiple stable isotopes. Limnol Oceanogr 40:622-625. doi:10.4319/ 10.1995.40.3.0622

Cabana G, Rasmussen JB (1996) Comparison of aquatic food chains using nitrogen isotopes. P Natl A Sci USA 93:10844-10847

Carabel S, Godinez-Dominguez E, Verisimo P, Fernandez L, Freire J (2006) An assessment of sample processing methods for stable isotope analyses of marine food webs. J Exp Mar Biol Ecol 336:254-261. doi:10.1016/j.jembe.2006.06.001

de Lecea AM, Cooper R, Omarjee A, Smit AJ (2011) The effects of preservation methods, dyes and acidification on the isotopic values $\left(\delta^{15} \mathrm{~N}\right.$ and $\left.\delta^{13} \mathrm{C}\right)$ of two zooplankton species from the KwaZulu-Natal Bight, South Africa. Rapid Commun Mass Sp 25:1853-1861. doi:10.1002/rcm.5051

DeNiro JM, Epstein S (1981) Influence of diet on the distribution of nitrogen isotopes in animals. Geochim Cosmochim Ac 45:341-351

Demopoulos AWJ, Fry B, Smith CR (2007) Food web structure in exotic and native mangroves: a Hawaii-Puerto Rico comparison. Oecologia 153:675-686. doi:10.1007/s00442-007-0751-x

Divine LM, Iken K, Bluhm BA (2015) Regional benthic food web structure on the Alaska Beaufort Sea shelf. Mar Ecol-Prog Ser 531:15-32. doi:10.3354/meps 11340

Edwards MS, Turner TF, Sharp ZD (2002) Short and long-term effects of fixation and preservation on stable isotope values $\left(\delta^{13} \mathrm{C}, \delta^{15} \mathrm{~N}, \delta^{34} \mathrm{~S}\right)$ of fluid-preserved museum specimens. Copeia 4:1106-1112

Fanelli E, Cartes JE, papiol V, Rumolo P, Sprovieri M (2010) Effects of preservation on the $\delta^{13} \mathrm{C}$ and $\delta^{15} \mathrm{~N}$ values of deepsea macrofauna. J Exp Mar Biol Ecol 395:93-97. doi:10.1016/ j.jembe. 2010.08 .020

Fantle MS, Dittel AI, Schwalm SM, Epifanio CE, Fogel ML (1999) A food web analysis of the juvenile blue crab, Callinectes sapidus, using stable isotopes in whole animals and individual amino acids. Oecologia 120:416-426. doi:10.1007/s004420050874

Feder HM, Iken K, Blanchard AL, Jewett SC, Schonberg S (2011) Benthic food web structure in the southeastern Chukchi Sea: an assessment using $\delta^{13} \mathrm{C}$ and $\delta^{15} \mathrm{~N}$ analyses. Polar Biol 34:521532. doi:10.1007/s00300-010-0906-9

Frost PC, Evans-White A, Finkel ZV, Jensen TC, Matzek V (2005) Are you what you eat? Physiological constraints on organismal stoichiometry in an elementally imbalanced world. Oikos 109:18-28. doi:10.1111/j.0030-1299.2005.14049.x

Frost PC, Stelzer RS, Lamberti GA, Elser JJ (2002) Ecological stoichiometry of trophic interactions in the benthos: understanding the role of C:N:P ratios in Lentic and Lotic habitats. J N Am Benthol Soc 21:515-528

Goering J, Alexander V, Haubenstock N (1990) Seasonal variability of stable carbon and nitrogen isotope ratios of organisms in a North Pacific Bay. Estuar Coast Shelf S 30:239-260. doi:10.1016/ 0272-7714(90)90050-2

Gontikaki E, Mayor DJ, Narayanaswamy BE, Witte UFM (2011) Feeding strategies of deep-sea sub-Arctic macrofauna of the Faroe-Shetland Channel: combining natural stable isotopes and enrichment techniques. Deep-Sea Res Pt I 58:160-172. doi:10.1016/j.dsr.2010.11.011

González-Bergonzoni I, Vidal N, Wang B, Ning D, Liu Z, Jeppesen E, Meerhoff M (2015) General validation of formalin-preserved fish samples in food web studies using stable isotopes. Methods Ecol Evol 6:307-314. doi:10.1111/2041-210X.12313

Grall J, Le Loc'h F, Guyonnet B, Riera P (2006) Community structure and food web based on stable isotopes $\left(\delta^{15} \mathrm{~N}\right.$ and $\left.\delta^{13} \mathrm{C}\right)$ analysis of a North Eastern Atlantic maerl bed. J Exp Mar Biol Ecol 338:1-15. doi:10.1016/j.jembe.2006.06.013

Hunter WR, Levin LA, Kitazato H, Witte U (2012) Macrobenthic assemblage structure and organismal stoichiometry control faunal processing of particulate organic carbon and nitrogen in oxygen minimum zone sediments. Biogeosciences 9:9931006. doi:10.5194/bg-9-993-2012

Iken K, Bluhm B, Dunton K (2010) Benthic food-web structure under differing water mass properties in the southern Chukchi Sea. Deep-Sea Res Pt II 57:71-85. doi:10.1016/j.dsr2.2009.08.007

Jacob U, Mintenbeck K, Brey T, Knust R, Beyer K (2005) Stable isotope food web studies: a case for standardized sample treatment. Mar Ecol-Prog Ser 287:251-253

Jaschinski S, Hansen T, Sommer U (2008) Effects of acidification in multiple stable isotope analyses. Limnol Oceanogr-Meth 6:12-15. doi:10.4319/lom.2008.6.12

Jeffreys RM, Burke C, Jamieson AJ, Narayanaswamy BE, Ruhl HA, Smith Jr KL, Witte U (2013) Feeding preferences of abyssal macrofauna inferred from in situ pulse chase experiments. 
PLoS One 8:e80510. doi:10.1371/journal.pone.0080510

Kazanidis G, Henry L-A, Roberts JM, Witte UFM (2016) Biodiversity of Spongosorites coralliophaga (Stephens, 1915) on coral rubble at two contrasting cold-water coral reef settings. Coral Reefs 35:193-208. doi:10.1007/s00338-015-1355-2

Kazanidis G Witte UFM (2016) The trophic structure of Spongosorites coralliophaga-coral rubble communities at two northeast Atlantic cold water coral reefs. Mar Biol Res 12:932-947. doi:10.1080/ 17451000.2016.1216569

King P, Kennedy H, Newton PP, Jickells TD, Brand T, Calvert S, Cauwet G, Etcheber H, Head B, Khripounoff A, Manighetti B, Miquel JC (1998) Analysis of total and organic carbon and total nitrogen in settling oceanic particles and a marine sediment: an interlaboratory comparison. Mar Chem 60:203216. doi:10.1016/S0304-4203(97)00106-0

Kolasinski J, Rogers K, Frouin P (2008) Effects of acidification on carbon and nitrogen stable isotopes of benthic macrofauna from a tropical coral reef. Rapid Commun Mass Sp 22:29552960. doi:10.1002/rcm.3694

Lau DC, Leung KMY, Dudgeon D (2012) Preservation effects on $\mathrm{C} / \mathrm{N}$ ratios and stable isotope signatures of freshwater fishes and benthic macroinvertebrates. Limnol Oceanogr-Meth 10:7589. doi:10.4319/lom.2012.10.75

Layman CA, Araujo MS, Boucek R, Hammerschlag-Peyer CM, Harrison E, Jud ZR, Matich P, Rosenblatt AE, Vaudo JJ, Yeager LA, Post DM, Bearhop S (2012) Applying stable isotopes to examine food-web structure: an overview of analytical tools. Biol Rev 87:545-562. doi:10.1111/j.1469-185X.2011.00208.x

Liu B, Liu Y, Li Y, Wang H, Xu J (2013) An assessment of sample preservation methods for the determination of stable carbon and nitrogen isotope ratios in mollusks. Anal Lett 46:2620-2634. doi:10.1080/00032719.2013.805415

Lohse L, Kloosterhuis RT, de Stigter HC, Helder W, van Raaphorst W, van Weering TCE (2000) Carbonate removal by acidification causes loss of nitrogenous compounds in continental margin sediments. Mar Chem 69:193-201. doi:10.1016/S0304-4203 (99)00105-X

Mateo MA, Serrano O, Serrano L, Michener RH (2008) Effects of sample preparation on stable isotope ratios of carbon and nitrogen in marine invertebrates: implications for food web studies using stable isotopes. Oecologia 157:105-115. doi:10.1007/ s00442-008-1052-8

Mazumder D, Iles J, Kelleway J, Kobayashi T, Knowles L, Saintilan N, Hollins S (2010) Effect of acidification on elemental and isotopic compositions of sediment organic matter and macroinvertebrate muscle tissues in food web research. Rapid Commun Mass Sp 24:2938-2942. doi:10.1002/rcm.4729

McCutchan, JH, William ML, Kendall C, McGrath CC (2003) Variation in trophic shift for stable isotope ratios of carbon, nitrogen, and sulfur. Oikos 102:378-390. doi:10.1034/j.16000706.2003.12098.x
Mill AC, Sweeting JC, Barnes C, Al-Habsi S, MacNeil AM (2008) Mass-spectrometer bias in stable isotope ecology. Limnol Oceanogr-Meth 6:34-39

Minagawa M, Wada E (1984) Stepwise enrichment of ${ }^{15} \mathrm{~N}$ along food chains: further evidence and the relations between $\delta^{15} \mathrm{~N}$ and animal age. Geochim Cosmochim Ac 48:1135-1140. doi:10.1016/0016-7037(84)90204-7

Mintenbeck K, Jacob U, Knust R, Arntz WE, Brey T (2007) Depthdependence in stable isotope ratio $\delta^{15} \mathrm{~N}$ of benthic POM consumers: the role of particle dynamics and organism trophic guild. Deep-Sea Res Pt I 54:1015-1023. doi:10.1016/j.dsr.2007.03.005

$\mathrm{Ng}$ JSS, Wai T-C, Williams GA (2007) The effects of acidification on the stable isotope signatures of marine algae and molluscs. Mar Chem 103:97-102. doi:10.1016/j.marchem.2006.09.001

Post DM (2002) Using stable isotopes to estimate trophic position: models, methods, and assumptions. Ecology 83:703-718. doi:10.1890/0012-9658(2002)083[0703:USITET]2.0.CO;2

Rennie MD, Ozersky T, Evans DO (2012) Effects of formalin preservation on invertebrate stable isotope values over decadal time scales. Can J Zoolog 90:1320-1327. doi:10.1139/z2012101

Roberts JM, Shipboard Party (2013) Changing oceans expedition 2012. Heriot-Watt University, Edinburgh, RRS James Cook 073 Cruise Report, $224 \mathrm{p}$

Ruiz-Cooley RI, Garcia KY, Hetherington ED (2011) Effects of lipid removal and preservatives on carbon and nitrogen stable isotope ratios of squid tissues: implications for ecological studies. J Exp Mar Biol Ecol 407:101-107. doi:10.1016/j.jembe. 2011.07.002

Sarakinos HC, Johnson ML, Vander Zanden MJ (2002) A synthesis of tissue preservation effects on carbon and nitrogen stable isotope signatures. Can J Zoolog 80:381-387

Schlacher TA, Connolly RM (2014) Effects of acid treatment on carbon and nitrogen stable isotope ratios in ecological samples: a review and synthesis. Methods Ecol Evol 5:541-550. doi:10.1111/2041-210X.12183

Serrano S, Serrano L, Mateo MA, Colombini I, Chelazzi L, Gagnarli E, Fallaci M (2008) Acid washing effect on elemental and isotopic composition of whole beach arthropods: Implications for food web studies using stable isotopes. Acta Oecol 34:89-96. doi:10.1016/j.actao.2008.04.002

Sokolowski A, Szczepańska A, Richard P, Kędra M, Wolowicz M, Węslawski JM (2014) Trophic structure of the microbenthic community of Hornsund, Spitsbergen, based on the determination of stable carbon and nitrogen isotopic. Polar Biol 37:12471260. doi:10.1007/s00300-014-1517-7

Søreide JE, Tamelander T, Hop H, Hobson KA, Johansen I (2006) Sample preparation effects on stable $\mathrm{C}$ and $\mathrm{N}$ isotope values: a comparison of methods in Arctic marine food web studies. Mar Ecol-Prog Ser 328:17-28. doi:10.3354/meps328017

Sterner RW, Elser JJ (2002) Ecological stoichiometry. Princeton 
University Press, Princeton, $382 \mathrm{p}$

Sweetman AK, Witte U (2008) Response of an abyssal macrofaunal community to a phytodetrital pulse. Mar Ecol-Prog Ser 355:73-84. doi:10.3354/meps07240

Syväranta J, Vesala S, Rask M, Ruuhijärvi J, Jones RI (2008) Evaluating the utility of stable isotope analyses of archived freshwater sample materials 600:121-130. doi:10.1007/s10750007-9181-3

Tu KL, Blanchard AL, Iken K, Horstmann-Dehn L (2015) Small-scale spatial variability in benthic food webs in the northeastern Chukchi Sea. Mar Ecol-Prog Ser 528:19-37. doi:10.3354meps11216

Vafeiadou A, Adao H, De Troch M, Moens T (2013) Sample acidification effects on carbon and nitrogen stable isotope ratios of macrofauna from a Zostera noltii bed. Mar Freshwater Res 64:741-745. doi:10.1071/MF12169

van Oevelen D, Duineveld G, Lavaleye M, Mienis F, Soetaert K, Heip CHR (2009) The cold-water coral community as a hot spot for carbon cycling on continental margins: a food-web analysis from Rockall Bank (northeast Atlantic). Limnol Oceanogr 54:1829-1844. doi:10.4319/lo.2009.54.6.1829

Vander Zanden MJ, Fetzer WW (2007) Global patterns of aquatic food chain length. Oikos 116:1378-1388. doi:10.1111/j.00301299.2007.16036.x
Vander Zanden MJ, Rasmussen JB (1999) Primary consumer $\delta^{13} \mathrm{C}$ and $\delta^{15} \mathrm{~N}$ and the trophic position of aquatic consumers. Ecology 80:1395-1404. doi:10.1890/0012-9658(1999)080 [1395:PCCANA]2.0.CO;2

Wolf N, Carleton SA, Martinez del Rio C (2009) Ten years of experimental animal isotopic ecology. Funct Ecol 23:17-26. doi:10.1111/j.1365-2435.2009.01529.x

$\mathrm{Xu}$ J, Zhang M, Xie P (2011) Sympatric variability of isotopic baselines influences modeling of fish trophic patterns. Limnology 12:107-115. doi:10.1007/s10201-010-0327-z

Yokoyama H, Sakami T, Ishihi Y (2009) Food sources of benthic animals on intertidal and subtidal bottoms in inner Ariake Sound, southern Japan, determined by stable isotopes. Estuar Coast Shelf S 82:243-253. doi:10.1016/j.ecss.2009.01.010

Yokoyama H, Tamaki A, Harada K, Shimoda K, Koyama K, Ishihi Y (2005) Variability of diet-tissue isotopic fractionation in estuarine macrobenthos. Mar Ecol-Prog Ser 296:115-128. doi:10.3354/ meps 29611

Publisher's Note Springer Nature remains neutral with regard to jurisdictional claims in published maps and institutional affiliations. 


\section{Appendix}

Table A1. Locations of sample collection in the east Canadian Arctic and cold-water coral reefs in the northeast Atlantic

\begin{tabular}{lccc}
\hline \hline & Latitude & Longitude & Depth (m) \\
\hline Canadian Arctic & & & \\
\hline Labrador Sea (633) & $57^{\circ} 36.49^{\prime} \mathrm{N}$ & $61^{\circ} 53.98^{\prime} \mathrm{W}$ & 187 \\
Baffin Bay (176) & $69^{\circ} 35.33^{\prime} \mathrm{N}$ & $65^{\circ} 47.11^{\prime} \mathrm{W}$ & 200 \\
Nares Strait (253b) & $79^{\circ} 19.26^{\prime} \mathrm{N}$ & $71^{\circ} 24.76^{\prime} \mathrm{W}$ & 201 \\
North Water Polynya (117) & $77^{\circ} 18.80^{\prime} \mathrm{N}$ & $76^{\circ} 57.40^{\prime} \mathrm{W}$ & 475 \\
Lancaster Sound (301) & $74^{\circ} 06.38^{\prime} \mathrm{N}$ & $83^{\circ} 20.62^{\prime} \mathrm{W}$ & 693 \\
\hline Cold-water coral reefs & & & $122-131$ \\
Mingulay reef Complex & $56^{\circ} 49.3^{\prime} \mathrm{N}$ & $7^{\circ} 23.6^{\prime} \mathrm{W}$ & $683-800$ \\
Logachev mound & $55^{\circ} 29.6^{\prime} \mathrm{N}$ & $15^{\circ} 49.1^{\prime} \mathrm{W}$ & \\
\hline
\end{tabular}

Table A2. Volume of $1 \mathrm{M}$ hydrochloric acid $(\mathrm{HCl})(\mu \mathrm{l})$ used for the carbonate removal of each species

\begin{tabular}{|c|c|c|c|c|c|c|c|}
\hline Species & Phylum & $\begin{array}{c}\mathrm{HCl} \text { added } \\
(\text { mean } \pm \text { S.D })\end{array}$ & $\mathrm{n}$ & Species & Phylum & $\begin{array}{c}\mathrm{HCl} \text { added } \\
(\text { mean } \pm \text { S.D })\end{array}$ & $\mathrm{n}$ \\
\hline Anthozoa indet. $^{\mathrm{a}}$ & CNI & $63.0 \pm 14.8$ & 6 & Gorgonocephalus sp. $^{\text {a }}$ & $\mathrm{ECH}$ & $210.0 \pm 0.0$ & 2 \\
\hline Parazoanthus anguicomus ${ }^{\mathrm{b}}$ & $\mathrm{CNI}$ & $45.00 \pm 0.0$ & 8 & Heliometra glacialis $^{\mathrm{a}}$ & $\mathrm{ECH}$ & $213.0 \pm 52.4$ & 5 \\
\hline Umbellula sp. $^{\mathrm{a}}$ & $\mathrm{CNI}$ & $60.0 \pm 0.0$ & 2 & Ophiacantha bidentata $^{\mathrm{a}}$ & $\mathrm{ECH}$ & $187.5 \pm 26.0$ & 4 \\
\hline Aristias neglectus ${ }^{\mathrm{b}}$ & ART & $60.0 \pm 0.0$ & 3 & Ophioctenella acies ${ }^{\mathrm{b}}$ & $\mathrm{ECH}$ & $150.0 \pm 0.0$ & 3 \\
\hline Galathea strigosa $^{\mathrm{b}}$ & ART & $60.0 \pm 0.0$ & 4 & Ophioctenella acies juveniles ${ }^{\mathrm{b}}$ & $\mathrm{ECH}$ & 165.0 & 1 \\
\hline Janira maculosa ${ }^{\mathrm{b}}$ & ART & 60.0 & 1 & Ophiopleura borealis ${ }^{\mathrm{a}}$ & $\mathrm{ECH}$ & $212.0 \pm 29.4$ & 15 \\
\hline Pagurus sp. ${ }^{\mathrm{a}}$ & ART & 75.0 & 1 & Ophiothrix fragilis ${ }^{\mathrm{b}}$ & $\mathrm{ECH}$ & $130.0 \pm 8.7$ & 3 \\
\hline Scalpellum scalpellum ${ }^{\mathrm{b}}$ & ART & $60.0 \pm 0.0$ & 2 & Ophiura ophiura & $\mathrm{ECH}$ & $110.0 \pm 12.3$ & 6 \\
\hline Asperarca nodulosa juveniles ${ }^{b}$ & MOL & 300.0 & 1 & Pontaster tenuispinus ${ }^{\mathrm{a}}$ & $\mathrm{ECH}$ & $210.0 \pm 97.2$ & 5 \\
\hline Margarites costalis ${ }^{\mathrm{a}}$ & MOL & $40.0 \pm 17.3$ & 3 & Porania pulvillus ${ }^{\mathrm{b}}$ & $\mathrm{ECH}$ & 150.0 & 1 \\
\hline Candidae sp. ${ }^{\text {b }}$ & BRY & $140.0 \pm 17.3$ & 3 & Psilaster andromeda ${ }^{\mathrm{a}}$ & $\mathrm{ECH}$ & $100.0 \pm 8.7$ & 3 \\
\hline Chartella barleei $^{\mathrm{b}}$ & BRY & $60.0 \pm 0.0$ & 3 & Strongylocentrotus droebachiensis ${ }^{\mathrm{a}}$ & $\mathrm{ECH}$ & $246.0 \pm 13.4$ & 5 \\
\hline Reteporella beaniana ${ }^{\mathrm{b}}$ & BRY & $135.0 \pm 54.1$ & 3 & Polycarpa pomaria ${ }^{\mathrm{b}}$ & ASC & $60.0 \pm 0.0$ & 5 \\
\hline 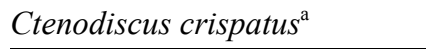 & $\mathrm{ECH}$ & $155.0 \pm 40.0$ & 6 & & & & \\
\hline
\end{tabular}

CNI: cnidarians; ART: arthropods; MOL: molluscs; BRY: bryozoans; ECH: echinoderms; ASC: ascidians; ${ }^{a}$ Arctic; ${ }^{b}$ cold-water coral reefs; Mean values and standard deviations are given. $n$ : number of replicates. 